\title{
GLOBAL NAVIGATION SATELLITE SYSTEMS APPLICATIONS IN DIFFERENT MODES OF TRANSPORT
}

DATA PRZESŁANIA: 30.06 .2016 | DATA AKCEPTACJI: 5.07.2016| KODY JEL: R42, Y10

\section{Jacek Januszewski}

Gdynia Maritime University

Faculty of Navigation

e-mail: jacekjot@am.gdynia.pl

\section{INTRODUCTION}

At the time of this writing (June 2016) more than 90 operational GPS, GLONASS, BeiDou, and Galileo (Satellite Navigation System - SNS), and EGNOS, MSAS, WAAS, GAGAN and SDCM (Satellite Based Augmentation System - SBAS), and QZSS and IRNSS (Regional Satellite Navigation System - RSNS) satellites are in Earth orbit transmitting a variety of signals on multiple frequencies. Two SNSs, GPS and GLONASS, and all SBASs except for SDCM are fully operational. All these systems are known also as GNSS (Global Navigation Satellite System). 
Several hundred million receivers of all these systems are used in each mode of transportation in the world - road, rail, maritime and air. Each user of transport can obtain its own position by one or more receivers of one or more SNS with or without GPS in differential mode (DGPS) and with or without one or more SBAS. Fix position by means of each mentioned above system is possible only on condition that the user is in the range of these systems and his receiver is able to utilize the signals from all these systems appropriately, (Betz, 2016; Januszewski, 2012, 2016; BeiDou; IAC; Inside GNSS).

Currently (June 2016) more than 5 billion different GNSS devices are used around the globe. By 2023, this is forecasted to increase to over $9 \mathrm{bln}$, it will be more than one device per person. The primary region of global market is, and will be, Asia-Pacific with the number of devices greater than EU and North America combined. In the case of EU28 and Non-EU28 Europe this number is in 2016 about one billion (GNSS Market Report, 2015).

\section{SEGMENTS IN GNSS MARKET REPORT}

In Europe one of the most comprehensive source of knowledge and information on the dynamic, global GNSS market is report published on average 15 months by European Global Navigation Satellite System Agency (GSA). In the first issue (October 2010) the number of GNSS market segments was equal 4 (Location Based Service - LBS, Agriculture and two connected with transport, Road and Aviation), in the second issue two segments were added (Surveying and next connected with transport, Maritime), in the third issue segment Rail, in the last issue (fourth) segment Timing Synchronization. The changes of the cumulative core revenue in each segment during last years are presented in the Table 1 . We can remark that the part of the road segment decreases incessantly, the part of six other segments (apart from Timing Synchronization) incessantly also but the part of all four transport segments is greater than $41 \%$.

The market size of core revenues refers to the value of only GNSS receivers and chipsets in different devices whereas enabled revenues include the full retail price of device, the price of smartphones in particular. The values of these two revenues, in euro, were in 2015 about 75 bln and 250 bln respectively. As both market sizes increase by few percentage annually we can expect that in 2023 these values will be about 110 bln and 300 bln respectively (GNSS Market Report, 2015).

The percentage of the GNSS integrated receivers (GPS system and/or SBAS or other SNS) depending on the system in different market segments is presented in the Table 2 . We can say that detailed distribution of multi-constellation GNSS receivers consisting of GPS receiver and one, two, three or four receivers of other systems showed that in the case both each four transport segments and all eight segments the greatest percentage is then if one of these systems is SBAS. In spite of two SNSs, Galileo and BeiDou, are still under construction GNSS receivers of these systems for the users of all modes of transport except for aviation are already available on the world market. For these systems the percentage is less than in the case of GPS and GLONASS which are fully operational. 
Table 1. GNSS Market Report, cumulative core revenue (in \%) in different market segments in different periods (GNSS Market Report, 2010, 2012, 2013, 2015)

\begin{tabular}{|c|c|c|c|c|}
\hline $\begin{array}{l}\text { Number of issue, month } \\
\text { and year, number of page }\end{array}$ & $\begin{array}{l}\text { 1, October } \\
2010,34\end{array}$ & $\begin{array}{c}2, \text { May } \\
2012,48\end{array}$ & $\begin{array}{c}\text { 3, October } \\
2013,72\end{array}$ & $\begin{array}{l}\text { 4, March } \\
2015,81\end{array}$ \\
\hline Segment Period & $2010-2020$ & $2010-2020$ & $2013-2022$ & $2013-2022$ \\
\hline Location Based Service & 42.8 & 43.7 & 47.0 & 53.2 \\
\hline Road & 56.4 & 54.0 & 46.2 & 38.0 \\
\hline Surveying & - & 0.6 & 4.1 & 4.5 \\
\hline Aviation & 0.2 & 0.5 & 1.0 & 1.1 \\
\hline Maritime & - & 0.1 & 0.3 & 1.1 \\
\hline Agriculture & 0.6 & 1.0 & 1.4 & 1.9 \\
\hline Rail & - & - & 0.1 & 0.2 \\
\hline Timing Synchronization & - & - & - & 0.1 \\
\hline
\end{tabular}

Source: author's own calculations based on GNSS Market Report (2010, 2012, 2013, 2015).

Table 2. Capability of GNSS multi-constellation receivers (in \%) according to GNSS Market Report in four segments connected with transport and in all eight market segments

\begin{tabular}{|l|c|c|c|c|c|}
\hline \multirow{2}{*}{$\begin{array}{c}\text { GPS system } \\
\text { and }\end{array}$} & \multicolumn{4}{|c|}{ Segment } & \multirow{2}{*}{$\begin{array}{c}\text { All eight } \\
\text { segments }\end{array}$} \\
\cline { 2 - 6 } & aviation & maritime & rail & road & 62 \\
\hline SBAS & 26 & 77 & 74 & 88 & 55 \\
\hline GLONASS & 2 & 68 & 69 & 61 & 36 \\
\hline Galileo & - & 53 & 42 & 46 & 25 \\
\hline BeiDou & - & 34 & 36 & 20 & \\
\hline
\end{tabular}

Source: author's own calculations based on GNSS Market Report (2015).

In the case of Galileo system the percentage is the biggest for maritime segment because its users count already on the benefits of two services, SAR (Search and Rescue) and SoL (Safety of Life), in particular. In the case of GLONASS system the percentage is for aviation segment lower considerably than for both all three other transport segments and all eight segments because currently in area transport one SNS is practically used only - GPS system.

Distribution of GNSS receivers (GPS only and multi-constellation) depending on the number of global SNS for four transport segments and for all eight segments is presented in the Table 3. We can find that:

- in area transport GNSS receivers with Galileo and/or BeiDou system, both systems still under construction, are not used,

- GNSS receivers of all four SNSs, two fully operational and two under construction, are already available for maritime, rail and road users, 
- as since few years GLONASS system is the second system of choice after GPS system, the GPS and GLONASS integrated receivers are very frequently used in all transport segments except for aviation segment,

- in the case of the GNSS receivers of two or three SNSs the lowest percentage is then if one of these systems is BeiDou.

Table 3. Distribution of GNSS receivers (in \%) depending on the number of the global satellite navigation systems in GNSS Market Report for four segments connected with transport and in all eight market segments

\begin{tabular}{|c|c|c|c|c|c|c|}
\hline \multirow{2}{*}{$\begin{array}{l}\text { Number } \\
\text { of the } \\
\text { systems }\end{array}$} & \multirow{2}{*}{ System } & \multicolumn{5}{|c|}{ Per cent } \\
\hline & & aviation & maritime & rail & road & all \\
\hline 1 & GPS only & 97 & 24.5 & 24 & 30 & 41 \\
\hline \multirow{3}{*}{2} & GPS + GLONASS & 3 & 22 & 32 & 24 & 22 \\
\hline & GPS + Galileo & - & 5 & 3 & 8 & 4 \\
\hline & GPS + BeiDou & - & 1.5 & - & - & 1 \\
\hline \multirow{3}{*}{3} & $\begin{array}{l}\text { GPS + GLONASS } \\
+ \text { Galileo }\end{array}$ & - & 12.5 & 6 & 12.5 & 8 \\
\hline & $\begin{array}{l}\text { GPS + GLONASS } \\
+ \text { BeiDou }\end{array}$ & - & - & - & 1.5 & 2 \\
\hline & $\begin{array}{l}\text { GPS + Galileo } \\
+ \text { BeiDou }\end{array}$ & - & - & 2 & - & 1 \\
\hline 4 & $\begin{array}{l}\text { GPS + GLONASS } \\
+ \text { Galileo + BeiDou }\end{array}$ & - & 34.5 & 33 & 24 & 21 \\
\hline \multicolumn{2}{|l|}{ Total (\%) } & 100 & 100 & 100 & 100 & 100 \\
\hline
\end{tabular}

Source: author's own calculations based on GNSS Market Report (2015).

Distribution of the installed base of GNSS devices (in per cent) in eight different regions of the world for aviation, maritime, rail and road market segment and for all eight market segments in 2013 and 2023 is presented in the Table 4. We can say that:

- aviation and maritime segments; the part of North America is, and will be, the biggest,

- rail segment; the biggest part in the world market will have Asia-Pacific and EU28,

- road segment; the biggest part in the market have currently EU28, North America and Asia-Pacific, in the future EU28 and Asia-Pacific,

- the part of Non-EU28, Middle East + Africa and South America + Caribbean is, and will be, in the case of each transport segment less than $10 \%$,

- in each region the devices used in aviation, maritime and rail segments are counted in thousands, in road segment in million and in all eight segments in billion. 
Table 4. Distribution of the installed base of GNSS devices (in \%) in eight different regions of the world for four segments connected with transport and all eight market segments in different years

\begin{tabular}{|c|c|c|c|c|c|c|c|c|c|c|}
\hline \multirow{3}{*}{ Region } & \multicolumn{10}{|c|}{ Segment } \\
\hline & \multicolumn{2}{|c|}{ aviation } & \multicolumn{2}{|c|}{ maritime } & \multicolumn{2}{|c|}{ rail } & \multicolumn{2}{|c|}{ road } & \multicolumn{2}{|c|}{$\begin{array}{l}\text { all eight } \\
\text { segments }\end{array}$} \\
\hline & 2013 & 2023 & 2013 & 2023 & 2013 & 2023 & 2013 & 2023 & 2013 & 2023 \\
\hline EU28 & 16.7 & 15.5 & 24.5 & 18.0 & \multirow{6}{*}{$x^{1}$} & 22.3 & 30.0 & 31.6 & 16.4 & 11.2 \\
\hline $\begin{array}{l}\text { Non-EU28 } \\
\text { Europe }\end{array}$ & 1.9 & 1.5 & 2.6 & 2.4 & & 16.7 & 4.6 & 5,7 & 5.7 & 6.2 \\
\hline North America & 68.2 & 64.7 & 48.0 & 46.4 & & 19.3 & 30.0 & 17.0 & 21.3 & 14.5 \\
\hline Asia-Pacific & 8.1 & 11.6 & 18.8 & 25.3 & & 37.0 & 27.7 & 34.0 & 41.8 & 45.6 \\
\hline $\begin{array}{l}\text { Middle East + } \\
\text { Africa }\end{array}$ & 1.6 & 2.0 & 5.2 & 5.5 & & 2.7 & 2.3 & 3.4 & 8.2 & 15.5 \\
\hline $\begin{array}{l}\text { South America } \\
+ \text { Caribbean }\end{array}$ & 3.5 & 4.7 & 0.9 & 2.4 & & 2.0 & 5.4 & 8.3 & 6.6 & 7.0 \\
\hline Per cent & 100 & 100 & 100 & 100 & 100 & 100 & 100 & 100 & 100 & 100 \\
\hline $\begin{array}{l}\text { Number } \\
\text { of the units }\end{array}$ & 946 & 1480 & 7330 & 14350 & 55 & 1126 & 239 & 641 & 2815 & 9157 \\
\hline Dimension & \multicolumn{2}{|c|}{ thousands } & \multicolumn{2}{|c|}{ thousands } & \multicolumn{2}{|c|}{ thousands } & \multicolumn{2}{|c|}{$\mathrm{mln}$} & \multicolumn{2}{|c|}{ bln } \\
\hline
\end{tabular}

$\mathrm{x}^{1}$ - detailed distribution unknown

Source: author's own calculations based on GNSS Market Report $(2013,2015)$.

Table 5. Distribution of the installed base of GNSS devices (in \%) by applications for four segments connected with transport in different years

\begin{tabular}{|l|c|c|l|c|c|c|}
\hline \multicolumn{1}{|c|}{ Segment and applications } & \multicolumn{2}{c|}{ Year } & \multicolumn{2}{c|}{ Segment and applications } & \multicolumn{2}{c|}{ Year } \\
\hline \multicolumn{1}{|c|}{ Aviation } & 2013 & 2023 & & 2013 & 2023 \\
\hline Commercial Aviation & 2 & 3 & & 5 & 6 \\
\hline Regional Aviation & 2.2 & 2.8 & Search \& Rescue (PLB) & 3.1 & 3.2 \\
\hline General \& Business Aviation & 1.7 & 1.6 & Search \& Rescue (EPIRB) & 2.6 & 2.5 \\
\hline Search \& Rescue (ELT) & 25.5 & 26.3 & Traffic Management & 1.0 & 0.7 \\
\hline Search \& Rescue (PLB) & 5.1 & 8.0 & Homeland Security & 1.6 & 0.6 \\
\hline General Aviation VFR & 8.8 & 11.1 & Inland Waterways Traffic Info & - & 1.4 \\
\hline Total (\%) & 56.7 & 50.2 & Ports & - & 0.7 \\
\hline Number of the units & 100 & 100 & Marine Engineering & - & - \\
\hline Dimension & 946 & 1480 & Fishing Vessels & 1.0 & 1.1 \\
\hline Road & thousands & Inland Waterways Navigation & 2.3 & 1.7 \\
\hline Personal Navigation Device & 2013 & 2023 & Merchant Navigation & 3.0 & 2.3 \\
\hline Road User Charching & 47.4 & 12.0 & Recreational Navigation & 85.4 & 85.8 \\
\hline Insurance telematics & 1.5 & 3.5 & Total (\%) & 100 & 100 \\
\hline In-Vehicle System & - & 2.6 & Number of the units & 7330 & 14350 \\
\hline eCall & 45.8 & 54.8 & Dimension & thousands \\
\hline
\end{tabular}




\begin{tabular}{|l|c|c|l|c|c|}
\hline \multicolumn{1}{|c|}{1} & 2 & 3 & & 4 & 5 \\
\hline Digital Tachograph & - & 0.3 & Assess Management & 60.0 & 83.6 \\
\hline ADAS & - & 3.5 & Passenger Information & 40.0 & 7.1 \\
\hline Total (\%) & 100 & 100 & Signalising and train control & - & 9.3 \\
\hline Number of the units & 239 & 641 & Total (\%) & 100 & 100 \\
\hline Dimension & \multicolumn{2}{|c|}{ mln } & Number of the units & 55 & 1126 \\
\hline & Dimension & thousands \\
\hline
\end{tabular}

Source: author's own calculations based on GNSS Market Report $(2013,2015)$.

Distribution of the installed base of GNSS devices (in per cent) by applications for four segments connected with transport in 2013 and 2023 is presented in the Table 5. The number of applications depends on the market segment; maritime -11 , road -7 , aviation -6 , rail -3 . The percentage is, and will be, the biggest in the case of recreational navigation, in-vehicle system, general aviation VFR (Visual Flight Rules) and assess management, respectively. Some applications, as insurance telematics, digital tachograph, ports in 2013 were unknown.

\section{GPS WORLD MAGAZINE, RECEIVER SURVEY}

The most known and certainly most comprehensive receiver survey of database of GPS and GNSS equipment is published in the magazine GPS World the number January each year. In this survey we can find detailed information, i.e. 19 performance parameters, about several hundred receivers provided by several dozen manufacturers. The receiver survey via performance parameter user environment and applications distinguishes 15 different types of the users. Four types of them - aviation (A), marine (M), navigation (N) and vehicle/vessel tracking (V) - were taken into account in this paper.

In the number from January 2016 this information is provided by 45 manufactures on more than 438 receivers. From among these 438 receivers 304 (83.1\%) provided by 33 (73.3\%) manufacturers available to be used by at least one from four mentioned above types of applications were designed for GPS system and one other SNS, RSNS or/and SBAS at least (GPS World)).

Table 6. The number and the percentage of the integrated GNSS receivers designed for different types of the user (A - aviation, $\mathrm{M}$ - marine, $\mathrm{N}$ - navigation, $\mathrm{V}$ - vehicle/vessel tracking), total number of the receivers - 304

\begin{tabular}{|l|c|c|c|c|}
\hline \multirow{2}{*}{ Parameter } & \multicolumn{4}{|c|}{ Type of the user } \\
\cline { 2 - 5 } & A & M & N & V \\
\hline $\begin{array}{l}\text { Number } \\
\text { of the receivers }\end{array}$ & 185 & 268 & 280 & 187 \\
\hline Percentage & 61 & 88 & 92 & 62 \\
\hline
\end{tabular}

Source: author's own calculations based on GPS World.

The number and the percentage of the integrated GNSS receivers designed for each type of the users (A, M, N and V) are presented in the Table 6. The percentage of navigation (92) and marine (88) user are both greater than in the case of aviation (61) and vehicle/vessel tracking (62). 
There are 111 receivers (36.5\%) designed for all four mentioned about types of the user, 28 among these receivers are at the same time the integrated GNSS receivers of all global and regional SNS and SBAS; e.g. 8 NovAtel models, 6 Septentrio models. The number of manufacturers without offer concerning receiver designed for given type of the user is equal 11 and 12 in the case of aviation and vehicle/vessel tracking user respectively (www.gpsworld.com).

\section{GNSS APPLICATIONS}

SNSs, GPS in particular, has been available for civil and military use for more than two decades. That period of time has witnessed the creation of numerous new SNS applications. In the case of transport the kind of GNSS applications depends on its mode.

For air navigation a GNSS can be used in three basic roles: as a primary navigation system that may include one or more integrated navigation sensors, as a supplement system that can be used alone without comparison to another system, and as a multisensory navigation system that can be used for navigation but only after it has been compared for integrity with a primary system on the aircraft (Prasad, Ruggieri, 2005). Satellite navigation provides the means for aircraft navigation for all phases of flight. Integrating local augmentation systems, GNSS will even provide the required level of performance for high-accuracy landing operations (Hofmann-Wellenhof, Lichtenegger, Wasle, 2008).

The use of satellite navigation in railway systems will impact all its components: fixed assets, mobile assets and human component. Satellite-based railway systems can be divided into four groups: GPS-based geodesy procedures, GPS-based train influence systems, railway transport systems and GPS-based passenger information systems (Prasad, Ruggieri, 2005).

The maritime industry was quick to adopt satellite navigation, and an estimated $87 \%$ of merchant shipping already uses global SNSs and SBASs for navigation and positioning. About $90 \%$ of world trade is carried by sea, and shipping accounts for around $40 \%$ of trade between EU-countries (Egnos). SBAS, EGNOS in particular, is providing the maritime sector with the accurate and reliable positioning it demands (Januszewski, 2014). The Federal Radionavigation Plan have defined marine navigation in terms of four phases - ocean, coastal, harbour/harbour approach and inland water. GNSS, currently GPS in particular, is able to satisfy many of the ocean and coastal phase performance requirements (Federal Radionavigation Plan, 2014).

In the case of road application the role of SNS, currently first of all GPS, in this technology is to continuously determine the vehicle's location. In obstructed areas, such as urban canyons, SNS is supplement by a terrestrial system such as the Dead Reckoning to overcome the GPS signal blockage (El-Rabbany, 2002). The other use of SNS technology in vehicle navigation can help reduce the number of accidental lane crossovers on the highways. The transit lines can use SNS to better track their bus services and to improve on-time performance (Jackson State University). Road navigation opportunities for GNSS are enormous. The incorporation of moving maps and databases into private passenger vehicles generates more demand for GPS products than all other vehicle markets combined (Kaplan, Hegarty, 2005).

\section{CONCLUSIONS}

The primary region of the use of satellite navigation systems in all four modes of transport is in the world and will be Asia-Pacific. The greatest and the lowest use of satellite navigation systems in transport in the world is in road and rail mode respectively. 
As GPS system is since more than 20 years incessantly fully operational the receivers of this system are the most frequently used in all modes of transport, in area mode in particular.

The integrated receivers are already available on the market but the greatest percentage, in all modes of transport, is then if one of the system besides GPS system is one or more satellite based augmentation systems.

As the transportation is the engine of economic growth satellite navigation and based augmentations systems are a technology that is, and will remain, absolutely vital to the transportation system across all modes. This technology can increase safety, reduce congestion, and improve efficiency.

The advantages of GNSS in the aviation domain are numerous and different. Satellite navigation allows for more efficient and flexible route selection. Moreover satellite navigation will increase the landing capacity at airports while enabling curved airport approaches.

The road applications encompass traditional areas like navigation, fleet management or guidance, but in future the GNSS will also be part of more sophisticated and intelligent systems, like automatic driver assistance systems or speed limit enforcement.

Maritime use of GNSS goes for beyond navigation at sea to include applications for search and rescue, inland waterways, environmental protection and sailing. In the case of maritime transport next versions of SBASs, EGNOS in particular, will support navigation applications for harbour entrances, harbour approaches and coastal waters.

\section{REFERENCES}

BeiDou Navigation Satellite System. Available at: en.beidou.gov.cn (22.06.2016).

Betz, J.W. (2016). Engineering Satellite-Based Navigation and Timing. New Jersey: John Wiley \& Sons.

Egnos. Available at: www.egnos-portal.eu (22.06.2016).

El-Rabbany, A. (2002). Introduction to GPS The Global Positioning System. Boston-London: Artech House. Federal Radionavigation Plan (2014). Department of Defence, Department of Homeland Security and Department of Transportation, National Technical Information Service. Springfield, Virginia.

GNSS Market Report (2010). Issue 1. Prague: The European GNSS Agency, October.

GNSS Market Report (2012). Issue 2. Prague: The European GNSS Agency, May.

GNSS Market Report (2013). Issue 3. Prague: The European GNSS Agency, October.

GNSS Market Report (2015). Issue 4. Prague: The European GNSS Agency, March.

GPS World. Available at: www.gpsworld.com (25.06.2016).

GPS. Available at: www.gps.gov (23.06.2016).

Hofmann-Wellenhof, B., Lichtenegger, H., Wasle, E. (2008). GNSS - Global Navigation Satellite Systems GPS, GLONASS, Galileo, and more. Wien-NewYork: Springer.

IAC. Available at: www.glonass-iac.ru (22.06.2016).

Inside GNSS. Available at: www.insidegnss.com (24.06.2016).

Jackson State University. Available at: www.jsums.edu (22.06.2016).

Januszewski, J. (2012). New satellite navigation systems and modernization of current systems, why and for whom? Scientific Journals Maritime University of Szczecin, 32 (104), 58-64.

Januszewski, J. (2014). Shipborne satellite navigation systems receivers, exploitation remarks. Scientific Journals of the Maritime University of Szczecin, 40 (112), 67-72.

Januszewski, J. (2016). The analysis of the possibility of the simultaneous use of two and more SNS in different modes of transport. $16^{\text {th }}$ International Conference Transport Systems Telematics. Katowice-Ustroń. 
Kaplan, E.D., Hegarty, C.J. (2006). Understanding GPS Principles and Applications. Boston-London: Artech House.

Prasad, R., Ruggieri, M. (2005). Applied Satellite Navigation Using GPS, Galileo, and Augmentations Systems. Boston-London: Artech House.

\section{Wykorzystanie globalnych nawigacyjnych systemów satelitarnych w różnych gałęziach transportu}

STRESZCZENIE

Obecnie (lipiec 2016) można wyróżnić cztery gałęzie transportu - drogowy, kolejowy, morski i lotniczy. W każdej z nich nieprzerwana znajomość bieżącej pozycji użytkownika jest jednym z najważniejszych czynników decydujących o bezpieczeństwie i ekonomii transportu. Informację o pozycji mogą zapewnić satelitarne systemy nawigacyjne SSN (GPS, GLONASS) i systemy wspomagające SBAS (WAAS, EGNOS, MSAS, GAGAN). Dwa kolejne globalne SSN i jeden SBAS są w trakcie budowy. W artykule udzielono odpowiedzi na kilka pytań: w jakiej gałęzi transportu w/w systemy są najczęściej stosowane i dlaczego oraz który system jest preferowany w poszczególnych gałęziach i rejonach świata. Dla każdej z czterech gałęzi porównano także zastosowania GNSS, możliwości odbiorników GNSS i wykorzystywanie przez nich satelitów różnych systemów, a dodatkowo przedstawiono wyniki analizy porównawczej odbiorników GNSS przeznaczonych dla poszczególnych gałęzi transportu. 